\title{
APOBEC3F wt Allele
}

National Cancer Institute

\section{Source}

National Cancer Institute. APOBEC3F wt Allele. NCI Thesaurus. Code C95273.

Human APOBEC3F wild-type allele is located in the vicinity of 22 q13.1 and is approximately $15 \mathrm{~kb}$ in length. This allele, which encodes DNA dC->dU-editing enzyme APOBEC-3F protein, is involved in the negative regulation of viral infection. 